\begin{tabular}{|c|l|}
\hline Title & $\begin{array}{l}\text { Temporal changes in community composition of heterotrophic bacteria during in situ iron enrichment in the western } \\
\text { subarctic Pacific (SEEDS-II) }\end{array}$ \\
\hline Author(s) & Kataoka, Takafumi; Suzuki, Koji; Hay akawa, Maki; Kudo, Isao; Higashi, Seigo; Tsuda, A tsushi \\
\hline Citation & $\begin{array}{l}\text { Deep Sea Research Part II : Topical Studies in Oceanography, 56(26), 2779-2787 } \\
\text { https://doi.org/10.1016j.dsr2.2009.06.013 }\end{array}$ \\
\hline Issue Date & 2009-12-15 \\
\hline Doc URL & http://hdl.handle.net/2115/44029 \\
\hline Type & article (author version) \\
\hline File Information & DSRII56-26_2779-2787.pdf \\
\hline
\end{tabular}

Instructions for use 


\title{
Temporal changes in community composition of heterotrophic bacteria during in situ iron enrichment in the western subarctic Pacific (SEEDS-II)
}

Takafumi Kataoka ${ }^{\mathrm{a}}$ *, Koji Suzuki, ${ }^{\mathrm{a}, \mathrm{b}}$, Maki Hayakawa ${ }^{\mathrm{a}}$, Isao Kudo ${ }^{\mathrm{c}}$, Seigo Higashi ${ }^{\mathrm{a}, \mathrm{b}}$, and Atsushi Tsuda ${ }^{\mathrm{d}}$

\author{
${ }^{\mathrm{a}}$ Graduate School of Environmental Science, Hokkaido University \\ Kita-ku, Sapporo 060-0810, Japan \\ ${ }^{b}$ Faculty of Environmental Earth Science, Hokkaido University \\ Kita-ku, Sapporo 060-0810, Japan \\ ${ }^{\mathrm{c}}$ Graduate School of Fisheries Sciences, Hokkaido University \\ Kita-ku, Sapporo 060-0813, Japan \\ ${ }^{\mathrm{d}}$ Ocean Research Institute, University of Tokyo \\ Nakano-ku, Tokyo 164-8639, Japan
}

*Corresponding author. Tel. : +81 117062251 ; fax : +81 117064864

E-mail address: tak-g-k@ees.hokudai.ac.jp (T. Kataoka) 


\section{Abstract}

Little is known about the effects of iron enrichment in high-nutrient, low chlorophyll (HNLC) waters on the community composition of heterotrophic bacteria, which are crucial to nutrient recycling and microbial food webs. Using denaturing gradient gel electrophoresis (DGGE) of $16 \mathrm{~S}$ rDNA fragments, we investigated the heterotrophic eubacterial community composition in surface waters during an in situ iron enrichment experiment (SEEDS-II) in the western subarctic Pacific during the summer of 2004. DGGE fingerprints representing the community composition of eubacteria differed inside and outside the iron-enriched patch. Sequencing of DGGE bands revealed that at least five phylotypes of $\alpha$-proteobacteria including Roseobacter, Cytophaga-Flavobacteria-Bacteroides (CFB), $\gamma$-proteobacteria, and Actinobacteria occurred in almost all samples from the iron-enriched patch. Diatoms did not bloom during SEEDS-II, but the eubacterial composition in the iron-enriched patch was similar to that in diatom blooms observed previously. Although dissolved organic carbon DOC accumulation was not detected in surface waters during SEEDS-II, growth of the Roseobacter clade might have been particularly stimulated after iron additions. Two identified phylotypes of CFB were closely related to the genus Saprospira, whose algicidal activity might degrade the phytoplankton assemblages increased by iron enrichment. These results suggest that the responses of heterotrophic bacteria to iron enrichment could differ among phylotypes during SEEDS-II.

Keywords: 16S rRNA gene; Bacterial community; Eubacteria; Iron enrichment; PCR-DGGE; SEEDS-II 


\section{Introduction}

Iron is a key element needed for assimilating inorganic and organic carbons into eukaryotic and prokaryotic cells, including heterotrophic bacteria (eubacteria and archaea), through metabolic processes (Pakulski et al., 1996; Tortell et al., 1996; Church et al., 2000). Since heterotrophic bacteria contain 1.5-2-fold higher iron:carbon ratios than phytoplankton, they might compete with phytoplankton when iron resources are limited (Maldonado and Price, 1999). However, unlike eukaryotic phytoplankton, many prokaryotic cells have the advantage of high affinity siderophore-mediated iron uptake systems and can take up iron from siderophores produced by other organisms (Granger and Price, 1999; Hutchins et al., 1999). From the results of past in situ iron fertilization experiments in high-nitrate, low-chlorophyll (HNLC) waters, ingestion of iron and dissolved organic carbon (DOC) released from phytoplankton are crucial factors influencing proliferation of heterotrophic bacteria (Cochlan, 2001; Hall and Safi, 2001; Oliver et al., 2004; Hale et al., 2006). Using bottle incubation experiments, Kirchman et al. (2000) found that carbon is the prominent factor influencing bacterial growth in a HNLC region off California, but iron quickly becomes limiting when carbon limitation is alleviated. Therefore, iron and carbon determine bacterial growth in HNLC waters, although water temperature can become a limiting factor in high-latitude HNLC regions (Nagata et al., 2001).

However, whether iron can alter the community composition of heterotrophic bacteria directly or indirectly is unclear (i.e., via phytoplankton; Eldridge et al., 2007), although iron addition generally leads to a floristic shift from mixed populations of autotrophic 
flagellates and small diatoms to large diatoms in HNLC waters (Tsuda et al. 2003; de Baar et al., 2005; Boyd et al., 2007). Riemann et al. (2000) and Pinhassi et al. (2004) showed that bacterial community structure also changes dramatically in response to changes in algal community composition. However, Hutchins et al. (2001) observed that iron addition resulted in increases in bacterial abundance and production, but showed only minor changes in bacterial community composition despite dramatic changes in phytoplankton community structure.

In this study, we investigated temporal changes in eubacterial community composition during a second in situ iron-enrichment experiment (SEEDS-II) in the western subarctic Pacific using a 16S ribosomal RNA gene-based fingerprint technique-denaturing gradient gel electrophoresis (DGGE). Because of higher sample throughput, DGGE and other fingerprint techniques are often more powerful than clone libraries for comparing microbial assemblages over time and space (Casamayor et al., 2002). However, bacterial community composition in the western subarctic Pacific has rarely been studied (Taniguchi and Hamasaki, 2008). During SEEDS-II, large diatoms did not bloom and autotrophic nanoflagellates such as cryptophytes and prasinophytes dominated the phytoplankton community in the iron-enriched patch (Suzuki et al., this issue). Therefore, SEEDS-II provided an excellent opportunity to examine whether bacterial community composition changes during a non-diatom bloom stimulated by iron addition.

\section{Materials and methods}




\subsection{Study area and sampling}

A mesoscale in situ iron enrichment experiment was conducted in the Western Subarctic Gyre (WSG) of the North Pacific $\left(48.5^{\circ} \mathrm{N}, 165.0^{\circ} \mathrm{E}\right)$ from 13 July to 27 August 2004 onboard the R/V Hakuhou Maru and the R/V Kilo Moana. General descriptions of the experiment are given in Tsuda et al. (2007) and are described here briefly. After an observation on day 0 (D0), dissolved iron (322 $\mathrm{kg}$ of iron as $\left.\mathrm{FeSO}_{4}\right)$ and the inert tracer $\mathrm{SF}_{6}$ were added to the surface mixed layer over an $8 \times 8 \mathrm{~km}$ area on 20 July 2004 . An increase in the concentration of dissolved iron at $5 \mathrm{~m}$ depth was observed, from $<0.02 \mathrm{nM}$ before iron addition to about $1.4 \mathrm{nM}$ on day 1 (Nishioka et al., this issue). Additional iron enrichment was conducted on 26 July 2004 (D6), and it increased the concentration of dissolved iron to $0.7 \mathrm{nM}$ at $5 \mathrm{~m}$ (Nishioka et al., this issue). Water masses inside and outside the iron-enriched patch were defined throughout a horizontal iron patch survey by detecting the inert tracer $\mathrm{SF}_{6}$ (Tsumune et al., this issue). During the $\mathrm{R} / \mathrm{V}$ Hakuho Maru cruise, seawater samples were collected inside the iron-enriched patch on D2, D4, D7, D10, D12, and D25, and outside the iron-enriched patch on D5, D8, D11, D31, and D32. Seawater samples were collected from $5 \mathrm{~m}$ depth with acid-clean Niskin bottles attached to a carousel multi-sampler (CTD-CMS) system.

\subsection{DNA extraction}


Seawater samples were filtered onto $47 \mathrm{~mm}$ Nuclepore polycarbonate filters $(0.2 \mu \mathrm{m}$ pore size $)$ with gentle vacuum pressure $(<150 \mathrm{mmHg})$ within $60 \mathrm{~min}$ of sampling. Filters were immediately placed in a deep freezer $\left(-80^{\circ} \mathrm{C}\right)$ and stored until analysis. DNA extraction was performed according to Katano et al. (2001) as follows. The filters were ground in a lysis solution $[30 \mu \mathrm{l}$ of $10 \% \mathrm{v} / \mathrm{v}$ sodium dodecyl sulfate, $500 \mu \mathrm{l}$ of Tris-EDTA (TE) buffer and $3 \mu 1$ of $10 \mathrm{mg} \mathrm{ml}^{-1}$ proteinase $\left.\mathrm{K}\right]$ with autoclaved plastic pestles and incubated at $37^{\circ} \mathrm{C}$ for $1 \mathrm{~h}$. Cell lysates were frozen and thawed three times. To remove polysaccharides, a mixture of cetyltrimethlammonium bromide (CTAB; Wako) and $0.7 \mathrm{M} \mathrm{NaCl}$ solution was added, and the solution was incubated at $65^{\circ} \mathrm{C}$ for 10 min. Polysaccharides and proteins were removed with chloroform-isoamyl alcohol (24:1) and then eliminated with phenol-chloroform-isoamyl alcohol (25:24:1). DNA precipitated with ice-cold isopropanol was rinsed with ice-cold $70 \%$ ethanol and resuspended in $100 \mu \mathrm{TE}$ buffer. Then the DNA in solution was precipitated with ice-cold 100\% ethanol, rinsed with ice-cold $70 \%$ ethanol, and resuspended in $47 \mu 1 \mathrm{TE}$ buffer. The molecular weight of DNA in each extract was determined by electrophoresis of $5 \mu 1$ of extracts on a $1.5 \%$ agarose gel with a 100 bp DNA ladder (New England Biolabs, Inc.). The concentration of DNA in extracts was quantified by a spectrophotometer (GeneQuant ${ }^{\mathrm{TM}}$; GE Healthcare) and adjusted to $1 \mathrm{ng} \mu \mathrm{l}^{-1}$ in TE buffer.

\subsection{PCR for $D G G E$}

We PCR-amplified $550 \mathrm{bp}$ of the eubacterial 16S rRNA gene using a universal primer complementary to positions 907-926 (Escherichia coli numbering; 
(5'-CCGTCAATTCMTTTGAGTTT-3') and complementary to positions 341-357 plus a GC clamp (5'- CGCCCGCCGCGCCCCGCGCCCGTCCCGCCGCCCCCGCCCGCCTACGGGAGGCAGCAG-3'; (Muyzer et al., 1993, 1999). PCR mixtures were prepared in a $20 \mu \mathrm{l}$ total volume containing $1 \times \mathrm{Ex} \mathrm{Taq}^{\mathrm{TM}}$ Buffer (TaKaRa), $2.2 \mathrm{mM}$ $\mathrm{MgCl}_{2}, 0.5 \mathrm{mM} \mathrm{dNTP}, 0.25 \mu \mathrm{M}$ of each primer, 2.5 units of Taq DNA polymerase (Ex Taq $^{\text {TM}}$; TaKaRa) and approximately 2 pg of template DNA. PCR conditions followed those of Muyzer et al. (1993) with the exception of initial denaturation at $95^{\circ} \mathrm{C}$ for $5 \mathrm{~min}$. PCR amplification was performed with 35 cycles using a thermal cycler (Eppendorf Mastercycler Personal). PCR products $(2 \mu 1)$ were loaded on a $1.5 \%$ agarose gel and electrophoresed with a 100 bp DNA ladder (New England Biolabs, Inc.). The agarose gel was stained with ethidium bromide (Et-Br) and photographed. Band density was determined using Gel-pro Analyzer ${ }^{\circledR}$ version 4.5 (MediaCybernetics).

PCR products (ca.75 ng of DNA) were loaded on $16 \times 16 \mathrm{~cm}, 1 \mathrm{~mm}$ thick, $6 \%$ polyacrylamide (acrylamide:bis $=37.5: 1$ ) gel containing a denaturing gradient of 25 to $70 \%$ from top to bottom ( $7 \mathrm{M}$ urea and $40 \%$ formamide were considered $100 \%$ denaturant). Electrophoresis was performed with a hot bath DGGE unit (Bio-Rad Laboratories) using $1 \times$ TAE running buffer $(20 \mathrm{mM}$ Tris, $10 \mathrm{mM}$ acetic acid, $0.5 \mathrm{mM}$ EDTA, $\mathrm{pH} 8.0$ ) at $60^{\circ} \mathrm{C}$ for $16 \mathrm{~h}$ at $85 \mathrm{~V}$. The gel was stained for $30 \mathrm{~min}$ in $1 / 10,000$ SYBR Gold (Molecular Probes, Inc.) and destained for $20 \mathrm{~min}$ in distilled water. The DGGE gel was visualized using an Invitrogen Safe Imager and photographed; high-resolution image was stored.

\subsection{Analysis of DGGE patterns}


DGGE images were analyzed with a one-dimensional gel analysis tool in the Gel-pro Analyzer®. To detect DGGE bands, a density profile was obtained for estimating the ratio of each band's intensity to the total. Bands with relative intensity of $\geq 0.4 \%$ were considered significant in this study. A binary matrix was constructed, taking into account the presence (1) and absence (0) of bands in each lane (Schäfer and Muyzer, 2001). The dissimilarity in band-pattern between pairs of samples on the same gel was calculated as a Dice coefficient $\left(S_{\text {Dice }}\right)$ :

$$
S_{\text {Dice }}=2 N_{\mathrm{AB}} /\left(N_{\mathrm{A}}+N_{\mathrm{B}}\right),
$$

where $\mathrm{N}_{\mathrm{AB}}$ is the number of bands found in both patterns, and $N_{\mathrm{A}}$ and $N_{\mathrm{B}}$ represent the total number of bands in samples A and B, respectively. A distance matrix was analyzed with unweighted pairwise grouping with mathematical averages (UPGMA) to cluster samples using a Ward pairwise algorithm. Statistical calculations were performed with R software (version 2.0.1).

\subsection{Sequencing analysis}

To obtain sequence information from DGGE bands, all visualized bands were excised using a clean razor blade. The cut bands were then washed twice using $2 \mathrm{ml}$ of sterilized Milli-Q water and frozen until re-amplification with PCR. About $1 \mathrm{~mm}^{3}$ of 
each band was directly re-amplified. PCR conditions followed Muyzer et al. (1993) except initial template denaturing at $95^{\circ} \mathrm{C}$ for $5 \mathrm{~min}$, followed by 20 cycles of denaturation $\left(1 \mathrm{~min}\right.$ at $\left.95^{\circ} \mathrm{C}\right)$, annealing $\left[1 \mathrm{~min}\right.$ at $65-55^{\circ} \mathrm{C}$ (touchdown $-1^{\circ} \mathrm{C}$ cycle $\left.\left.{ }^{-1}\right)\right]$, and extension $\left(3 \mathrm{~min}\right.$ at $\left.72^{\circ} \mathrm{C}\right)$, followed by 7 cycles of denaturing $\left(1 \mathrm{~min}\right.$ at $\left.94^{\circ} \mathrm{C}\right)$, annealing $\left(1 \mathrm{~min}\right.$ at $\left.55^{\circ} \mathrm{C}\right)$, and extension $\left(3 \mathrm{~min} 72^{\circ} \mathrm{C}\right)$, with a final extension $\left(7 \mathrm{~min}\right.$ at $\left.72^{\circ} \mathrm{C}\right)$. After re-amplified bands were examined with DGGE to confirm their band position and non-contamination, PCR products were purified using the polyethylene glycol (PEG) precipitation method. A $15 \mu \mathrm{l}$ subsample of the amplified 16S rDNA solution was diluted with $35 \mu 1$ of distilled water and mixed with $30 \mu 1$ of PEG solution [20\% PEG 6000 (Wako) and 2.5 M NaCl], incubated on ice for an hour, and centrifuged at 15,000 rpm for 15 min. Precipitates were rinsed with ice-cold 70\% ethanol and resuspended in $20 \mu 1$ of distilled water. The purified amplified products were sequenced on an ABI PRISM ${ }^{\circledR} 3100$ Genetic Analyzer (Applied Biosystems) with both the 907-926 and 341-357 primers without the GC-clamp (Muyzer et al., 1993) using a BigDye v1.0 Terminator cycle sequencing kit (Applied Biosystems). Duplicate samples were analyzed to reduce reading errors by the genetic analyzer. Then 16S rDNA sequences were analyzed for each sample.

\subsection{Phylogenetic analysis}

Sequences obtained in this study were examined for chimeras, which could be generated artificially by co-amplification of homologous genes during PCR reactions, using the Ribosomal Database Project's CHECK-CHIMERA program (Maidak et al., 
1999). We also checked for chimeras with the basic local alignment search tool BLAST (Altschul et al., 1997) for short sequences. Non-chimeric sequences were compared to sequences deposited in the bacterial nucleotide sequence databases (i.e., ddbjbct and ddbjenv) of the DNA Data Bank of Japan (DDBJ). Acquired 16S rRNA gene sequences were assigned to phylogenetic groups based on the most similar sequence found in the DDBJ. Bacterial sequences were aligned using CLUSTAL W, and corrected manually to delete ambiguous and non-informative bases with Mega 3 (Kumar et al., 2004). A distance tree was constructed using the neighbor-joining (NJ) method based on Jukes and Cantor (1969) distance. Bootstrap resampling was performed 10,000 times. Newly determined sequences were deposited in Genbank (accession numbers AB355748-AB355784).

\subsection{Bacterial abundance and production}

The abundance of heterotrophic bacteria at $5 \mathrm{~m}$ was obtained from Kudo et al. (this issue). Their methodology is briefly described below. Duplicate water samples (2 $\mathrm{ml})$ were fixed with paraformaldehyde $(0.2 \%(\mathrm{w} / \mathrm{v})$ final concentration) and stored in a deep freezer $\left(-85^{\circ} \mathrm{C}\right)$ or liquid nitrogen until analysis. Bacterial cells were stained with a working solution of SYBR Green I ( $10^{-3}$ of the commercial solution, Molecular Probes). Samples were mixed with Flow-count fluorospheres (Beckman Coulter) and analyzed with an EPICS flow cytometer (XL ADC system; Beckman Coulter) following Suzuki et al. (2005). Data were analyzed with EXPO32 (Beckman Coulter).

Bacterial production data were also obtained from Kudo et al. (this issue). Bacterial carbon production was estimated by measuring ${ }^{3} \mathrm{H}$-leucine uptake to bacterial 
proteins (Kirchman et al., 1985; Simon and Azam, 1989). Triplicate water samples were incubated with ${ }^{3} \mathrm{H}$-labeled leucine at ambient temperature in the dark for $6 \mathrm{~h}$. Uptake was terminated by addition of trichloroacetic acid. Particulate matter was collected on a 0.22 $\mu \mathrm{m}$ membrane filter and the filter was placed into a scintillation cocktail (Ultima Gold AB; PerkinElmer). Radioactivity was measured with a Wallec 1414 liquid scintillation counter, and bacterial production was calculated using ${ }^{3} \mathrm{H}$ radioactivity and the standard conversion factors of Simon and Azam (1989).

\section{Results}

The abundance of heterotrophic bacteria at $5 \mathrm{~m}$ was $2.0 \times 10^{5}$ cells $\mathrm{ml}^{-1}$ on D0 before iron enrichment (Fig. 1A). In the iron-enriched patch, abundance was $0.9 \times 10^{5}$ cells $\mathrm{ml}^{-1}$ on $\mathrm{D} 2$ and increased to a maximum of $4.1 \times 10^{5}$ cells $\mathrm{ml}^{-1}$ on $\mathrm{D} 14$. Thereafter cell density decreased to $2.3 \times 10^{5}$ cells $\mathrm{ml}^{-1}$ on $\mathrm{D} 25$. In contrast, heterotrophic bacterial abundance outside the iron-enriched patch was stable until D18 with the exception of D11 and thereafter declined with time. Bacterial carbon production was $6.3 \mu \mathrm{g} \mathrm{C} \mathrm{m} \mathrm{d}^{-1}$ on D0 (Fig. 1B). The bacterial production in the upper $5 \mathrm{~m}$ of the iron-enriched patch was $4.2 \mu \mathrm{g} \mathrm{C} \mathrm{m} \mathrm{m}^{-3} \mathrm{~d}^{-1}$ on $\mathrm{D} 2$, increased to $8.3 \mu \mathrm{g} \mathrm{C}$ $\mathrm{m}^{-3} \mathrm{~d}^{-1}$ on D12, and then remained $>5 \mu \mathrm{g} \mathrm{C} \mathrm{m}^{-3} \mathrm{~d}^{-1}$. Bacterial carbon production in the upper $5 \mathrm{~m}$ outside the iron-enriched patch ranged between 2 and $6 \mu \mathrm{g} \mathrm{C} \mathrm{m} \mathrm{d}^{-1}$ throughout the experiment.

Ten to 20 bands were detected in each sample, and unique 46 band positions were determined (Fig. 2). Based on band composition, the clustering of 12 samples 
was determined using the Dice dissimilarity coefficient (Fig. 3). At 85\% dissimilarity, the samples were divided into two groups. Five of six samples (i.e., except the D10 sample) were derived from outside the iron-enriched patch. Similarly, five of six samples (i.e., except the D32 outside sample) originated from the iron-enriched patch. Five samples from the iron-enriched patch were characterized by the presence of bands l, q, za, and zb, which rarely occurred outside the patch (Fig. 2).

We succeeded in DNA-sequencing for 30 of 46 band positions (a-zd in Fig. 2). The band positions of $\mathrm{h}, \mathrm{k}, \mathrm{l}, \mathrm{o}, \mathrm{q}, \mathrm{w}$ and $\mathrm{y}$ were composed of multiple sequences, and we identified 37 sequences. Of the 37 sequences, 31 were more than $97 \%$ homologous with sequences deposited in the DDBJ. Homology levels for the other six sequences (i.e., sequence names CZII_k1, CZII_l1, CZII_12, CZII_m, CZII_v and CZII_w1) were less than 97\%. Sequence CZII_v was too short for further phylogenetic analysis. Overall, the 36 sequences identified in this study were more than $93 \%$ homologous with 55 closest relatives (Table 1). Even in the highly homologous sequences, phylogenetic affiliations of the six phylotypes (CZII_f, CZII_h2, CZII_q3, CZII_r, CZII_s and CZII_t) could not be identified with a BLAST search.

In the NJ tree of $\alpha$-proteobacteria (Fig.4) in which the Archaea Sulfolobus solfataricus was used as an outgroup, 31 sequences were clustered into four groups: Roseobacter, Methylobacterium, SAR11 and the other. Sequences CZII_q3 and CZII_r belonged to the Roseobacter group. Similarly, in the NJ tree for the remaining sequences in which $S$. solfataricus was used as an outgroup (Fig. 5), 65 sequences were clustered into seven groups that consisted exclusively of the following organisms or organelles: $\quad$ Cytophaga-Flavobacteria-Bacteroides $\quad(\mathrm{CFB}), \quad \gamma$-proteobacteria, 
Actinobacteria, Cyanobacteria, plastid of Eukaryota, chloroplast and the other. For new or affiliation-unknown sequences, CZII_s was $\gamma$-proteobacteria; CZII_t was Actinobacteria; CZII_l1 and CZII_12 were genus Saprospira; CZII_k1, CZII_m, CZII_f, and CZII_h2 were CFB; and CZII_w1 belonged to the other group.

Overall, phylogenetic analyses showed that the 36 sequences determined in this study consisted of 10 -proteobacteria (6 Roseobacter, 2 SAR11, 1

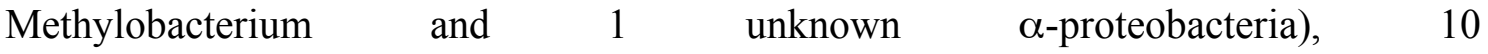
Cytophaga-Flavobacteria-Bacteroides (CFB) $\quad(8$ CFB and 2 Saprospira), 3 $\gamma$-proteobacteria, 4 Actinobacteria, 3 cyanobacteria, 2 plastids, 3 chloroplasts and 1 unknown organism or organelle. In the band positions of $\mathrm{l}, \mathrm{q}, \mathrm{za}$, and $\mathrm{zb}$, which were characteristic of the iron-enriched patch, $\mathrm{q}$ was classified as a Roseobacter, and CZII_q1 was a member of subgroup NAC11-3 whose cultivation has not yet been archived yet. In this subgroup, the 16S rDNA clones NAC11-3 and Arctic96A-1 are known to occur in DOC-rich waters (González et al., 2000; Bano and Hollibaugh, 2002), and CZII_q2 and CZII_q3 were close to NAC11-6 (Fig. 4), which was previously observed during an algal bloom (González et al., 2000).

\section{Discussion}

In SEEDS-II, the abundance and production of heterotrophic bacteria in surface waters inside the iron-enriched patch increased by approximately four- and twofold, respectively, by D14, compared to those on D2 (Fig. 1), indicating that the heterotrophic 
bacteria were stimulated after iron enrichment. The iron fertilizations altered the community composition of not only phytoplankton (Suzuki et al., this issue) but also of heterotrophic bacteria. Bacterial community composition generally differed between inside and outside the iron-enriched patch (Fig. 3), with the exception of one sample collected from inside the iron-enriched patch on D10 (discussed below). The results from the SEEDS-II experiment differed from previous iron enrichment experiments by Hutchins et al. (2001) and Arrieta et al. (2004). Hutchins et al. (2001) found that the eubacterial community composition in the subarctic Pacific, the Southern Ocean, and the California coastal upwelling region scarcely changed after iron infusions, although eubacterial abundance and production increased. Similarly, Arrieta et al. (2004) also reported that the eubacterial community composition during EisenEx, which was an in situ iron fertilization experiment carried out in the Southern Ocean, was relatively stable inside and outside the iron-enriched patch. However, Eldridge et al. (2007) recently showed that the eubacterial community changed in response to iron availability in the Peruvian upwelling region of the equatorial Pacific Ocean. Our results are similar to those of Eldridge et al. (2007), but we could not determine whether changes in bacterial community composition were induced by iron directly and/or indirectly (i.e., via phytoplankton) during SEEDS-II.

The responses of heterotrophic bacteria to iron infusion could differ among phylotypes. Eldridge et al. (2007) proposed that groups of bacteria within a microbial community respond differently to alterations in resources. This differential response occurs because changing the dynamics of a single resource will likely affect coexistence patterns, as that resource may be limiting to some species, causing population increases 
and driving down other resources that may be limiting for other species (Hutchinson, 1961). During SEEDS-II, the haplotypes CZII_q1 and CZII_q2, corresponding to bands $\mathrm{q} 1$ and $\mathrm{q} 2$ in Fig. 1, respectively, among the five phylotypes of heterotrophic bacteria characteristic of the iron-enriched patch, were identified as Roseobacter species ( $\alpha$-proteobacteria). In particular, CZII_q1 was affiliated with the subgroup NAC11-3 of the Roseobacter-clade-affiliated (RCA) cluster, whose habitat is cold or temperate waters, and not tropical and subtropical oceans (Selje et al., 2004). These $\alpha$-proteobacteria including Roseobacter were notably detected in the development phase, and that observation is consistent with the appearance of $\alpha$-proteobacteria during the exponential phase of diatom growth (Grossart et al., 2005).

Preferential use of phytoplankton products by the Roseobacter group has been reported (e.g., Morán et al., 2002; Grossart et al., 2005; Howard et al., 2006). Pinhassi et al. (2004) showed that Roseobacter species in the northwest Mediterranean Sea increased in density when the DOC concentration increased with algal blooms. Roseobacter also degrades demethylsulfoniopropionate (DMSP) to dimethylsulfide (DMS; González et al., 1999; Malmstrom et al., 2004). The occurrence of Roseobacter on D2 was concurrent with high DMS yields observed on that day (Lizotte et al., this issue), suggesting that Roseobacter played a key role in DMS production. This is in agreement with Zubkov et al. (2002) and Pinhassi et al. (2005), who reported that the Roseobacter group degraded DMSP to DMS during phytoplankton blooms. The q1 and q2 bands related to Roseobacter did not appear in the sample collected from the iron-enriched patch on D10 (Fig. 2) when the chlorophyll $a$ level at $5 \mathrm{~m}$ was near its peak during SEEDS-II (Tsuda et al., 2007). The reason for this is unknown, but Kudo 
et al. (this issue) found a decrease in bacterial production on D10 during SEEDS-II. We speculate that the disappearance of these Roseobacter phylotypes might have contributed to the decline in bacterial production.

CZII_l1, za, and zb were also typical in the iron-enriched patch during SEEDS-II, and these were classified as CFB, $\gamma$-proteobacteria, and Actinobacteria, respectively. According to DeLong et al. (1993), Pinhassi et al. (2004), and Grossart et al. (2005), CFB appear in the development or declining phases of phytoplankton blooms. Sequence CZII_11 clustered with genus Saprospira, belonging to CFB. Saprospira are known to possess algicidal activity; they can kill eukaryotic phytoplankton such as Chlorophyceae, Rhodophyceae, Bacillariophyceae, Dinophyceae, Haptophyceae and Raphidophyceae (Furusawa et al., 2003; Mayali and Azam, 2004). As these phytoplankton groups (except Rhodophyceae and Raphidophycae) existed in surface waters during SEEDS-II (Suzuki et al., this issue), CZII_l1 could have attacked the phytoplankton and increased their own density by consuming DOC from dead algal cells.

The quantity and/or quality of DOC from phytoplankton can affect bacterial community composition (Pinhassi et al., 2004). During SEEDS-II, the phytoplankton biomass at $5 \mathrm{~m}$ depth increased after the iron additions and reached a maximum of about $3 \mu \mathrm{g}^{-1}$ in terms of chlorophyll $a$ concentration on D12 (Tsuda et al., 2007). At that time, the phytoplankton assemblage was dominated by autotrophic nanoflagellates (Suzuki et al., this issue). Nearly concomitant increases in abundance and composition of phytoplankton and heterotrophic bacteria during SEEDS-II indicate that bacterial growth in the iron-enriched patch was mainly dependent on the release of DOC from 
the phytoplankton assemblage. However, ambient DOC levels in the iron-enriched patch during SEEDS-II were not statistically different from those outside the patch (Yoshimura et al., this issue), suggesting that high turnover rates of bioavailable DOC might conceal DOC accumulation in surface waters (Norrman et al., 1995). This speculation is supported by high turnover rates of DOC observed during a phytoplankton bloom in a mesocosm experiment (Smith et al., 1995) and in natural environments (North Atlantic Ocean, Kirchman et al., 1991; eastern North Pacific, Cherrier et al., 1996).

In addition to resources such as iron and DOC, heterotrophic nanoflagellates (HNFs) and temperature can affect the abundance and composition of heterotrophic bacteria. During an iron fertilization experiment (SOIREE) in the Southern Ocean, relatively high feeding rates of HNFs kept the cell density of heterotrophic bacteria relatively constant, although bacterial production increased (Hall and Safi, 2001). Unfortunately, the effects of HNFs feeding on the abundance and composition of heterotrophic bacteria were not examined in the WSG in the past or during SEEDS-II. More detailed studies should investigate the top-down control of HNF on heterotrophic bacteria in the study area. As for a temperature effect, Nagata et al. (2001) noted that water temperature could become a limiting factor for bacterial growth in the western subarctic Pacific. During SEEDS-II, water temperature at $5 \mathrm{~m}$ depth gradually increased with time, from $8.3^{\circ} \mathrm{C}$ on $\mathrm{D} 1$ to $11.7^{\circ} \mathrm{C}$ on $\mathrm{D} 32$. However, the water temperature was almost the same inside and outside the iron-enriched patch, indicating that water temperature was not related to the difference in bacterial composition inside and outside the iron patch. 


\section{Conclusions}

Here we investigated the effect of iron fertilization on the composition of heterotrophic bacteria. We found that iron additions altered the community composition of bacteria in surface waters, where phytoflagellates such as cryptophytes and prasinophytes bloomed. The 32 phylotypes identified in the eubacterial community in the WSG were dominated by 10 phylotypes of $\alpha$-proteobacteria and 10 Cytophaga-Flavobacteria-Bacteroides (CFB). Our results are consistent with the typical community composition of heterotrophic bacteria in pelagic oceans as determined with 16S rDNA libraries (Bano and Hollibaugh, 2002; Malmstrom et al., 2007; Taniguchi and Hamasaki, 2008). Furthermore, the occurrence of CFB and Roseobacter during the non-diatom bloom of SEEDS-II was similar to results obtained in previous diatom blooms (DeLong et al., 1993; Pinhassi et al., 2004; Grossart et al., 2005). Some specific phylotypes, such as CZII_q1 included in the RCA cluster of Roseobacter and CZII_l1 Saprospira-related phylotypes in the CFB, responded quickly to iron enrichment, suggesting that responses of eubacteria to iron infusion differ among phylotypes. The Roseobacter identified in this study is able to adapt to both low temperatures (Selje et al., 2004) and low DOC concentration (Alonso and Pernthaler, 2006), indicating that this phylotype could adapt to the WSG condition from winter to early spring. According to Kawakami and Honda (2007), annual particulate organic carbon flux and the export ratio (e-ratio) in the WSG are much higher than those in other oceans due to the higher production and transport of carbon by diatoms that 
proliferate every spring (Imai et al., 2002). Since heterotrophic bacteria play a critical part of the biological carbon pump as carbon consumers, further studies of heterotrophic bacteria in the WSG should be conducted to better understand their ecology and relevance to biogeochemical cycles.

\section{Acknowledgments}

We thank all the scientists who participated in SEEDS-II for their contributions to the success of this experiment. We also thank the captain and crew of the R/V Hakuho Maru for their field assistance. Dr. D. Munroe and two anonymous reviewers are acknowledged for their valuable comments and suggestions.

\section{References}

Alonso, C., Pernthaler, J., 2006. Roseobacter and SAR11 dominate microbial glucose uptake in coastal North Sea waters. Environmental Microbiology 8 (11), 2022-2030.

Altschul, S.F., Madden, T.L., Schäffer, A.A., Zhang, J.H., Zhang, Z., Miller, W., Lipman, D.J., 1997. Gapped BLAST and PSI-BLAST: a new generation of protein database search programs. Nucleic Acids Research 25 (17), 3389-3402 and $<$ http://www.ddbj.nig.ac.jp/ search/blast-j.html>.

Arrieta, J.M., Weinbauer, M.G., Lute, C., Herndl, G.J., 2004. Response of bacterioplankton to iron fertilization in the Southern Ocean. Limnology and Oceanography 49 (3), 799-808. 
Bano, N., Hollibaugh, J.T., 2002. Phylogenetic composition of bacterioplankton assemblages from the Arctic Ocean. Applied and Environmental Microbiology $68(2), 505-518$.

Boyd, P.W., Jickells, T., Law, C.S., Blain, S., Boyle, E.A., Buesseler, K.O., Coale, K.H., Cullen, J.J., de Baar, H.J.W., Follows, M., Harvey, M., Lancelot, C., Levasseur, M., Owens, N.P.J., Pollard, R., Rivkin, R.B., Sarmiento, J., Schoemann, V., Smetacek, V., Takeda, S., Tsuda, A., Turner, S., Watson, A.J., 2007. Mesoscale iron enrichment experiments 1993-2005: Synthesis and future directions. Science 315 (5812), 612-617.

Casamayor, E.O., Massana, R., Benlloch, S., Øvreås, L., Díez, B., Goddard, V.J., Gasol, J.M., Joint, I., Rodríguez-Valera, F., Pedrós-Alió, C., 2002. Changes in archaeal, bacterial and eukaryal assemblages along a salinity gradient by comparison of genetic fingerprinting methods in a multipond solar saltern. Environmental Microbiology 4 (6), 338-348.

Cherrier, J., Bauer, J.E., Druffel, E.R.M., 1996. Utilization and turnover of labile dissolved organic matter by bacterial heterotrophs in eastern north Pacific surface waters. Marine Ecology Progress Series 139 (1-3), 267-279.

Church, M.J., Hutchins, D.A., Ducklow, H.W., 2000. Limitation of bacterial growth by dissolved organic matter and iron in the Southern Ocean. Applied and Environmental Microbiology 66 (2), 455-466.

Cochlan, W.P., 2001. The heterotrophic bacterial response during a mesoscale iron enrichment experiment (IronEx II) in the eastern equatorial Pacific Ocean. Limnology and Oceanography 46 (2), 428-435. 
de Baar, H.J.W., Boyd, P.W., Coale, K.H., Landry, M.R., Tsuda, A., Assmy, P., Bakker, D.C.E., Bozec, Y., Barber, R.T., Brzezinski, M.A., Buesseler, K.O., Boyé, M., Croot, P.L., Gervais, F., Gorbunov, M.Y., Harrison, P.J., Hiscock, W.T., Laan, P., Lancelot, C., Law, C.S., Levasseur, M., Marchetti, A., Millero, F.J., Nishioka, J., Nojiri, Y., van Oijen, T., Riebesell, U., Rijkenberg, M.J.A., Saito, H., Takeda, S., Timmermans, K.R., Veldhuis, M.J.W., Waite, A.M., Wong, C.S., 2005. Synthesis of iron fertilization experiments: From the iron age in the age of enlightenment. Journal of Geophysical Research-Oceans 110, C9S16, doi:10.1029/2004JC002601.

DeLong, E.F., Franks, D.G., Alldredge, A.L., 1993. Phylogenetic diversity of aggregate-attached vs. free-living marine bacterial assemblages. Limnology and Oceanography $38(5), 924-934$.

Eldridge, M.L., Cadotte, M.W., Rozmus, A.E., Wilhelm, S.W., 2007. The response of bacterial groups to changes in available iron in the eastern sbtropical Pacific Ocean. The Journal of Experimental Marine Biology and Ecology 348, 11-22.

Furusawa, G., Yoshikawa, T., Yasuda, A., Sakata, T., 2003. Algicidal activity and gilding motility of Saprospira sp. SS98-5. Canadian Journal of Microbiology $49(2), 92-100$.

González, J.M., Simó, R., Massana, R., Covert, J.S., Casamayor, E.O., Pedrós-Alió, C., Moran, M.A., 2000. Bacterial community structure associated with a dimethylsulfoniopropionate-producing North Atlantic algal bloom. Applied and Environmental Microbiology 66 (10), 4237-4246.

González, J.M., Kiene, R.P., Moran, M.A., 1999. Transformation of sulfur compounds 
by an abundant lineage of marine bacteria in the $\alpha$-subclass of the class Proteobacteria. Applied and Environmental Microbiology 65 (9), 3810-3819.

Granger, J., Price, N.M., 1999. The importance of siderophores in iron nutrition of heterotrophic marine bacteria. Limnology and Oceanography 44 (3), 541-555.

Grossart, H.P., Levold, F., Allgaier, M., Simon, M., Brinkhoff, T., 2005. Marine diatom species harbour distinct bacterial communities. Environmental Microbiology 7 (6), 860-873.

Hale, M.S., Rivkin, R.B., Matthews, P., Agawin, N.S.R., Li, W.K.W., 2006. Microbial response to a mesoscale iron enrichment in the NE subarctic Pacific: Heterotrophic bacterial processes. Deep-Sea Research II 53 (20-22), 2231-2247.

Hall, J.A., Safi, K., 2001. The impact of in situ Fe fertilisation on the microbial food web in the Southern Ocean. Deep-Sea Research II 48 (11-12), 2591-2613.

Howard, E.C., Henriksen, J.R., Buchan, A., Reisch, C.R., Büergmann, H., Welsh, R., Ye, W.Y., González, J.M., Mace, K., Joye, S.B., Kiene, R.P., Whitman, W.B., Moran, M.A., 2006. Bacterial taxa that limit sulfur flux from the ocean. Science 314 (5799), 649-652.

Hutchins, D.A., Campbell, B.J., Cottrell, M.T., Takeda, S., 2001. Response of marine bacterial community composition to iron additions in three iron-limited regimes. Limnology and Oceanography 46 (6), 1535-1545.

Hutchins, D.A., Witter, A.E., Butler, A., Luther, G.W., 1999. Competition among marine phytoplankton for different chelated iron species. Nature 400 (6747), 858-861. 
Hutchinson, G.E., 1961. The paradox of the plankton. American Naturalist 95, 137-145. Imai, K., Nojiri, Y., Tsurushima, N., Saino, T., 2002. Time series of seasonal variation of primary productivity at station $\mathrm{KNOT}\left(44^{\circ} \mathrm{N}, 155^{\circ} \mathrm{E}\right)$ in the sub-arctic western North Pacific. Deep-Sea Research II 49, 5395-5408.

Jukes, T.H., Cantor, C.R., 1969. Mammalian protein metabolism. In: Munro, H.N. (Ed.), Evolution of protein molecules. Academic Prss, New York, pp. 21-132.

Katano, T., Fukui, M., Watanabe, Y., 2001. Identification of cultured and uncultured picocyanobacteria from a mesotrophic freshwater lake based on the partial sequences of 16S rDNA. Limnology 2, 213-218.

Kawakami, H., Honda, M.C., 2007. Time-series observation of POC fluxes estimated from ${ }^{234} \mathrm{Th}$ in the northwestern North Pacific. Deep-Sea Research I 54, 1070-1090.

Kirchman, D.L., Meon, B., Cottrell, M.T., Hutchins, D.A., Weeks, D., Bruland, K.W., 2000. Carbon versus iron limitation of bacterial growth in the California upwelling regime. Limnology and Oceanography 45 (8), 1681-1688.

Kirchman, D.L., Suzuki, Y., Garside, C., Ducklow, H.W., 1991. High turnover rates of dissolved organic-carbon during a spring phytoplankton bloom. Nature 352 (6336), 612-614.

Kirchman, D., K'nees, E., Hodson, R., 1985. Leucine incorporation and its potential as a measure of protein-synthesis by bacteria in natural aquatic systems. Applied and Environmental Microbiology 49 (3), 599-607.

Kudo, I., Noiri, Y., Cochlan, W.P., Suzuki, K., Aramaki, T., Ono, T., Nojiri, Y., this issue. Primary production, bacterial production and nitrogen assimilation 
dynamics during the SEEDS-II experiment.

Kumar, S., Tamura, K., Nei, M., 2004. MEGA3: Integrated software for molecular evolutionary genetics analysis and sequence alignment. Briefings in Bioinformatics 5 (2), 150-163.

Lizotte, M., Levasseur, M., Kudo, I., Suzuki, K., Tsuda, A., Kiene, R.P., Scarratt, G.M., this issue. Iron-induced alterations of bacterial DMSP metabolism during SEEDS-II.

Maidak, B.L., Cole, J.R., Parker, C.T., Garrity, G.M., Larsen, N., Li, B., Lilburn, T.G., McCaughey, M.J., Olsen, G.J., Overbeek, R., Pramanik, S., Schmidt, T.M., Tiedje, J.M., Woese, C.R., 1999. A new version of the RDP (Ribosomal Database Project). Nucleic Acids Research 27 (1), 171-173 and $<\mathrm{http}: / /$ rdp8.cme.msu.edu/cgis/chimera.cgi?su=SSU $>$.

Maldonado, M.T., Price, N.M., 1999. Utilization of iron bound to strong organic ligands by plankton communities in the subarctic Pacific Ocean. Deep-Sea Research II 46 (11-12), 2447-2473.

Malmstrom, R.R., Straza, T.R.A., Cottrell, M.T., Kirchman, D.L., 2007. Diversity, abundance, and biomass production of bacterial groups in the western Arctic Ocean. Aquatic Microbial Ecology 47 (1), 45-55.

Malmstrom, R.R., Kiene, R.P., Kirchman, D.L., 2004. Identification and enumeration of bacteria assimilating dimethylsulfoniopropionate (DMSP) in the North Atlantic and Gulf of Mexico. Limnology and Oceanography 49 (2), 597-606.

Mayali, X., Azam, F., 2004. Algicidal bacteria in the sea and their impact on algal blooms. Journal of Eukaryotic Microbiology 51 (2), 139-144. 
Morán, X.A.G., Estrada, M., Gasol, J.M., Pedrós-Alió, C., 2002. Dissolved primary production and the strength of phytoplankton bacterioplankton coupling in contrasting marine regions. Microbial Ecology 44 (3), 217-223.

Muyzer, G., 1999. DGGE/TGGE a method for identifying genes from natural ecosystems. Current Opinion in Microbiology 2 (3), 317-322.

Muyzer, G., de Waal, E.C., Uitterlinden, A.G., 1993. Profiling of complex microbial populations by denaturing gradient gel electrophoresis analysis of polymerase chain reaction-amplified genes coding for $16 \mathrm{~S}$ rRNA. Applied and Environmental Microbiology 59 (3), 695-700.

Nagata, T., Fukuda, R., Fukuda, H., Koike, I., 2001. Basin-scale geographic patterns of bacterioplankton biomass and production in the subarctic Pacific, July-September 1997. Journal of Oceanography 57 (3), 301-313.

Nishioka, J., Takeda, S., Kondo, Y., Obata, H., Doi, T., Tsumune D., Wong, C.S., Johnson, W. K., Tsuda, A., this issue. Changes in iron concentration and bio-availability during an open ocean mesoscale iron enrichment in the western subarctic Pacific, SEEDS II.

Norrman, B., Zweifel, U.L., Hopkinson, C.S., Fry, B., 1995. Production and utilization of dissolved organic carbon during an experimental diatom bloom. Limnology and Oceanography 40 (5), 898-907.

Oliver, J.L., Barber, R.T., Smith, W.O., Ducklow, H.W., 2004. The heterotrophic bacterial response during the Southern Ocean Iron Experiment (SOFeX). Limnology and Oceanography 49 (6), 2129-2140.

Pakulski, J.D., Coffin, R.B., Kelley, C.A., Holder, S.L., Downer, R., Aas, P., Lyons, 
M.M., Jeffrey, W.H., 1996. Iron stimulation of Antarctic bacteria. Nature 383 (6596), 133-134.

Pinhassi, J., Simó, R., González, J.M., Vila, M., Alonso-Sáez, L., Kiene, R.P., Moran, M.A., Pedrós-Alió, C., 2005. Dimethylsulfoniopropionate turnover is linked to the composition and dynamics of the bacterioplankton assemblage during a microcosm phytoplankton bloom. Applied and Environmental Microbiology $71(12), 7650-7660$.

Pinhassi, J., Sala, M.M., Havskum, H., Peters, F., Guadayol, Ò., Malits, A., Marrasé, C.L., 2004. Changes in bacterioplankton composition under different phytoplankton regimens. Applied and Environmental Microbiology 70 (11), 6753-6766.

Riemann, L., Steward, G.F., Azam, F., 2000. Dynamics of bacterial community composition and activity during a mesocosm diatom bloom. Applied and Environmental Microbiology 66 (2), 578-587.

Schäfer, H., Muyzer, G., 2001. Denaturing gradient gel electrophoresis in marine microbial ecology. In: Paul, J.H. (Ed.), Marine Microbiology. Academic press, San Diego, pp. 425-468.

Selje, N., Simon, M., Brinkhoff, T., 2004. A newly discovered Roseobacter cluster in temperate and polar oceans. Nature 427 (6973), 445-448.

Simon, M., Azam, F., 1989. Protein-content and protein-synthesis rates of planktonic marine-bacteria. Marine Ecology Progress Series 51 (3), 201-213.

Smith, D.C., Steward, G.F., Long, R.A., Azam, F., 1995. Bacterial mediation of carbon fluxes during a diatom bloom in a mesocosm. Deep-Sea Research II 42 (1), 
$75-97$.

Suzuki, K., Saito, H., Isada, T., Hattori, A., Kiyosawa, H., Nishioka, J., McKay, R.M.L., Kuwata, A., Tsuda, A., this issue. Community structure and photosynthetic physiology of phytoplankton in the northwest subarctic Pacific during an in situ iron fertilization experiment.

Suzuki, K., Hinuma, A., Saito, H., Kiyosawa, H., Liu, H.B., Saino, T., Tsuda, A., 2005. Responses of phytoplankton and heterotrophic bacteria in the northwest subarctic Pacific to in situ iron fertilization as estimated by HPLC pigment analysis and flow cytometry. Progress in Oceanography 64 (2-4), 167-187.

Taniguchi, A., Hamasaki, K., 2008. Community structures of actively growing bacteria shift along a north-south transect in the western North Pacific. Environmental Microbiology 10 (4), 1007-1017.

Tortell, P.D., Maldonado, M.T., Price, N.M., 1996. The role of heterotrophic bacteria in iron-limited ocean ecosystems. Nature 383 (6598), 330-332.

Tsuda, A., Takeda, S., Saito, H., Nishioka, J., Kudo, I., Nojiri, Y., Suzuki, K., Uematsu, M., Wells, M.L., Tsumune, D., Yoshimura, T., Aono, T., Aramaki, T., Cochlan, W.P., Hayakawa, M., Imai, K., Isada, T., Iwamoto, Y., Johnson, W.K., Kameyama, S., Kato, S., Kiyosawa, H., Kondo, Y., Levasseur, M., Machida, R.J., Nagao, I., Nakagawa, F., Nakanishi, T., Nakatsuka, S., Narita, A., Noiri, Y., Obata, H., Ogawa, H., Oguma, K., Ono, T., Sakuragi, T., Sasakawa, M., Sato, M., Shimamoto, A., Takata, H., Trick, C.G., Watanabe, Y.W., Wong, C.S., Yoshie, N., 2007. Evidence for the grazing hypothesis: Grazing reduces phytoplankton responses of the HNLC ecosystem to iron 
enrichment in the western subarctic Pacific (SEEDS II). Journal of Oceanography 63 (6), 983-994.

Tsuda, A., Takeda, S., Saito, H., Nishioka, J., Nojiri, Y., Kudo, I., Kiyosawa, H., Shiomoto, A., Imai, K., Ono, T., Shimamoto, A., Tsumune, D., Yoshimura, T., Aono, T., Hinuma, A., Kinugasa, M., Suzuki, K., Sohrin, Y., Noiri, Y., Tani, H., Deguchi, Y., Tsurushima, N., Ogawa, H., Fukami, K., Kuma, K., Saino, T., 2003. A mesoscale iron enrichment in the western subarctic Pacific induces a large centric diatom bloom. Science 300 (5621), 958-961.

Tsumune, D., Nishioka, J., Shimamoto, A., Watanabe, W. Y., Aramaki, T., Nojiri, Y., Takeda, S., Tsuda, A., this issue. Physical behaviors of iron fertilized path in SEEDS-II.

Yoshimura T., Ogawa H., Imai K., Aramaki T., Nojiri Y., Nishioka J., Tsuda A., this issue. The dynamics and elemental stoichiometry of carbon, nitrogen, and phosphorus in particulate and dissolved organic pools during a phytoplankton bloom induced by in situ iron enrichment in the western subarctic Pacific (SEEDS-II).

Zubkov, M.V., Fuchs, B.M., Archer, S.D., Kiene, R.P., Amann, R., Burkill, P.H., 2002. Rapid turnover of dissolved DMS and DMSP by defined bacterioplankton communities in the stratified euphotic zone of the North Sea. Deep-Sea Research II 49 (15), 3017-3038. 
Table and Figures.

Table 1 Closest relative sequences of $16 \mathrm{~S}$ rRNA gene from excited DGGE bands obtained during SEEDS-II experiment.

\begin{tabular}{|c|c|c|c|c|}
\hline \multicolumn{2}{|c|}{ Obtained sequenc's } & \multicolumn{3}{|c|}{ Closest relative's } \\
\hline Name* & Accession No. & Group"** & Description & Similarity $(\%)$ \\
\hline CZII_a & AB355748 & $\alpha, \mathrm{SAR} 11$ & clone Arctic96A-7 & 99.4 \\
\hline CZII_e & AB355750 & $\alpha$ SAR 11 & clone Arctic $96 \mathrm{~A}-20$ & 100.0 \\
\hline CZII_ol & AB355765 & $\alpha, \operatorname{Rosec}$ & clone RCAI1-2 & 99.0 \\
\hline CZII_o2 & AB3555766 & $\alpha, \operatorname{Roseo}$ & clone RCA11-2 & 100.0 \\
\hline CZII_qI & AB355768 & $\alpha, \operatorname{Roseo}$ & clone Arctic $96 \mathrm{~A}-1$ & 100.0 \\
\hline CZII_q2 & AB355769 & $\alpha$ Roseo & clone $\mathrm{NAC} 11.6$ & 100.0 \\
\hline $\mathrm{CZII} \times$ & AB355777 & $\alpha$ & clone 145 & 99.0 \\
\hline CZII ze & AB355783 & $\alpha$ Methy & Methylobacterizm aguaticum & 99.8 \\
\hline CZII_b & AB355749 & CFB & clone SPOTSAPR01_5m179 CFB8 & 99.8 \\
\hline CZII_f & AB355753 & unknown & clone ctg_CGOF037 & 99.6 \\
\hline CZII g & AB355754 & Bacteroidetes & clone PI_RT311 & 99.6 \\
\hline CZII_hl & AB355755 & Bacteroidetes & clone PI_RT311 & 99.6 \\
\hline CZII_kI & AB355759 & Bacteroidetes & clone $3 \mathrm{~B} 02-03$ & 96.9 \\
\hline CZII_11 & AB355761 & Bacteroidetes & Saprospira sp, SS03-3 & 96.7 \\
\hline CZII_12 & AB355762 & Bacteroidetes & Saprospira sp. SS03-3 & 95.9 \\
\hline CZII_m & AB355763 & Bacteroidetes & clone $\mathrm{M} 0-\mathrm{Ar} 2=\mathrm{P} 2 \mathrm{G} 08$ & 95.8 \\
\hline CZII_n & AB355764 & Flavobacteria & clone F289 & 98.3 \\
\hline CZII_p & AB355767 & $\gamma$ & ZD040S & 99.3 \\
\hline CZII_za & AB355781 & $\gamma$ & clone BJS72-004 & 100.0 \\
\hline CZII_h2 & AB355756 & unknown & clone AntCL1G3 & 98.9 \\
\hline CZII_q3 & AB355770 & unknown & clone ctg_CGOF316 & 98.1 \\
\hline CZII r & AB355771 & unknown & clone ctg_CGOF080 & 100.0 \\
\hline CZII_s & AB355772 & unknown & clone SPOTSAUG01_5m49 & 98.1 \\
\hline CZII_t & AB355773 & unknown & clone 9-sw-sus-1 & 98.5 \\
\hline CZII_v** & AB355774 & unknown & clone AntCLIDI & 96.9 \\
\hline CZII_w1 & AB355775 & unknown & $\mathrm{HOClCi} 47$ & 96.6 \\
\hline CZII_z & AB355780 & Actinobacteria & Gordonia otitidis IFM1048 & 100.0 \\
\hline CZII_zb & AB355782 & Actinobacteria & Propionibacterium acnes W1392 & 100.0 \\
\hline CZII_zd & AB355784 & Actinobacteria & Friedmanniella spumicola & 99.2 \\
\hline CZII_yl & AB355778 & Cya & clone PI_RT111 & 100.0 \\
\hline CZII_y2 & AB355779 & Cya,Synechococcus & clone SPOTSOCT01_5m10 clade4 & 99.8 \\
\hline CZII_w2 & AB355776 & Cya,Prochlorococcus & Prochlorococcus marinus MIT 9301 & 99.6 \\
\hline CZII_d & AB355751 & Chl,diatom & clone 111 & 98.1 \\
\hline CZII_e & AB355752 & $\mathrm{Chl}$ & Asterionella glacialis & 97.7 \\
\hline CZII_k2 & AB 355760 & $\mathrm{Chl}$ & DGGE gel band FD 23 & 99.6 \\
\hline $\mathrm{CZII} \underline{i}$ & AB355757 & plastid & clone OMS & 98.7 \\
\hline CZII j & AB355758 & plastid & prasinophyte DGGE band GB2-ell-FL & 100.0 \\
\hline
\end{tabular}

* Sequence names correspond to band positions (cf. Fig. 2)

** Too short sequence to use phylogenetic analysis

$* * * \alpha$ and $\gamma$ represent $\alpha$ - and $\gamma$-proteobacteria, respectively. Roseo, Methy, Cya and Chl represent Roseobacter, Methylobacter, Cyanobacteria and Chloroplast, respectively 


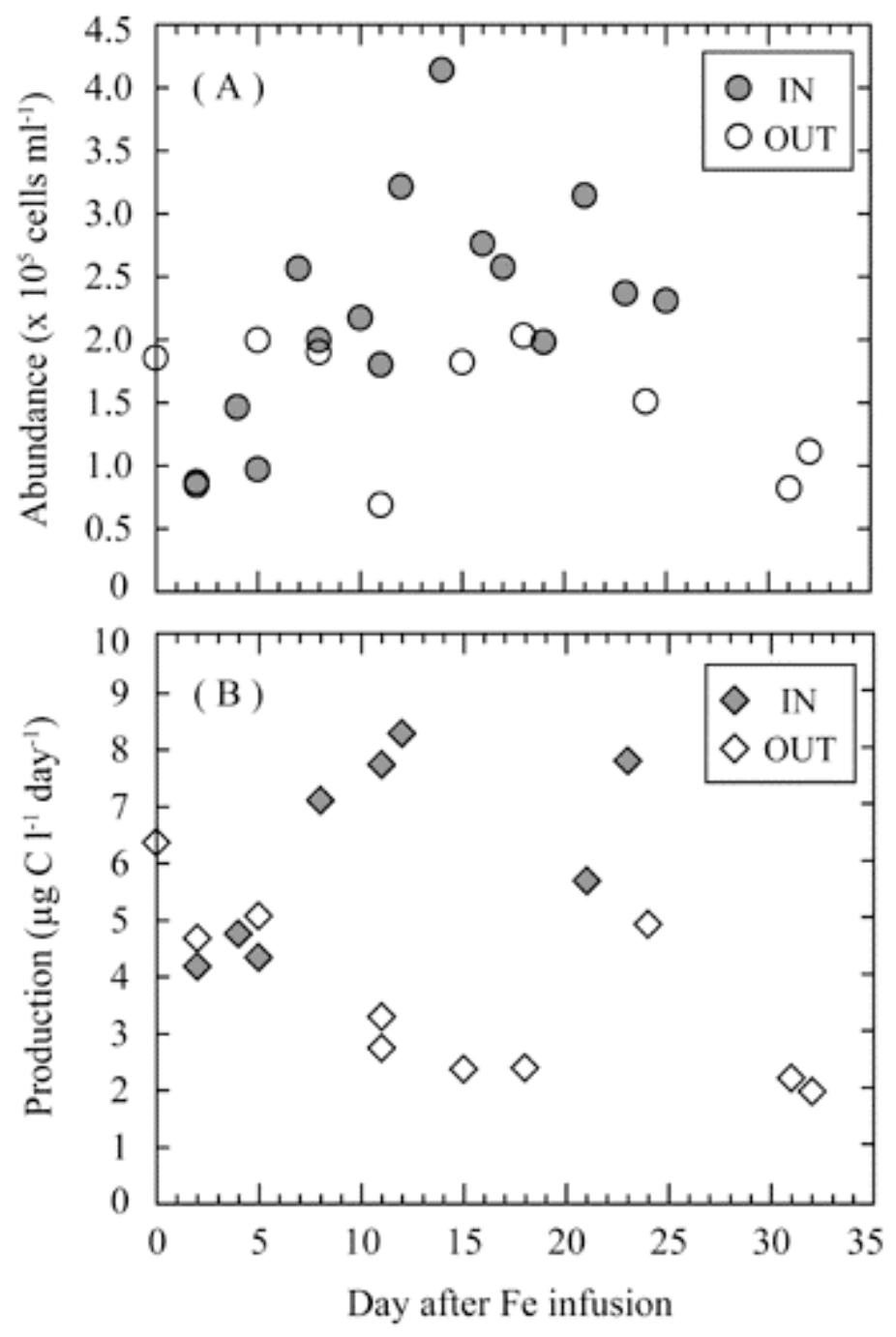

Fig. 1. Temporal changes in bacterial (A) abundance at $5 \mathrm{~m}$ and (B) carbon production in the upper $5 \mathrm{~m}$ inside and outside the iron-enriched patch. The data were derived from Kudo et al. (this issue). 


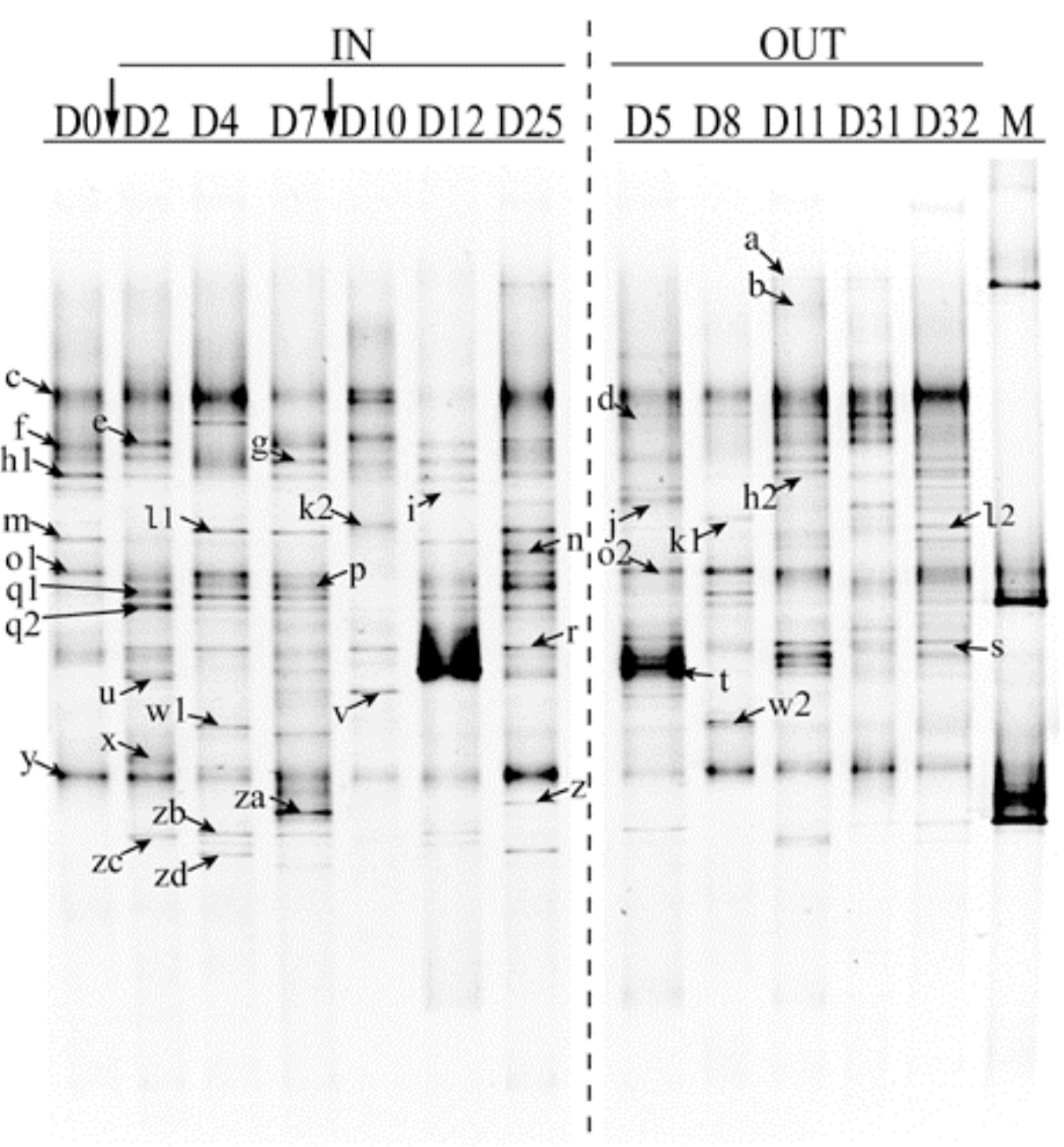

Fig. 2. Denaturing gradient gel electrophoresis (DGGE) profiles of eubacterial community composition inside (IN) and outside (OUT) the iron-enriched patch. Lane D0 represents a sample collected immediately before iron enrichment. Arrows indicate the days on which iron was added. Lane M includes the DNA markers. 


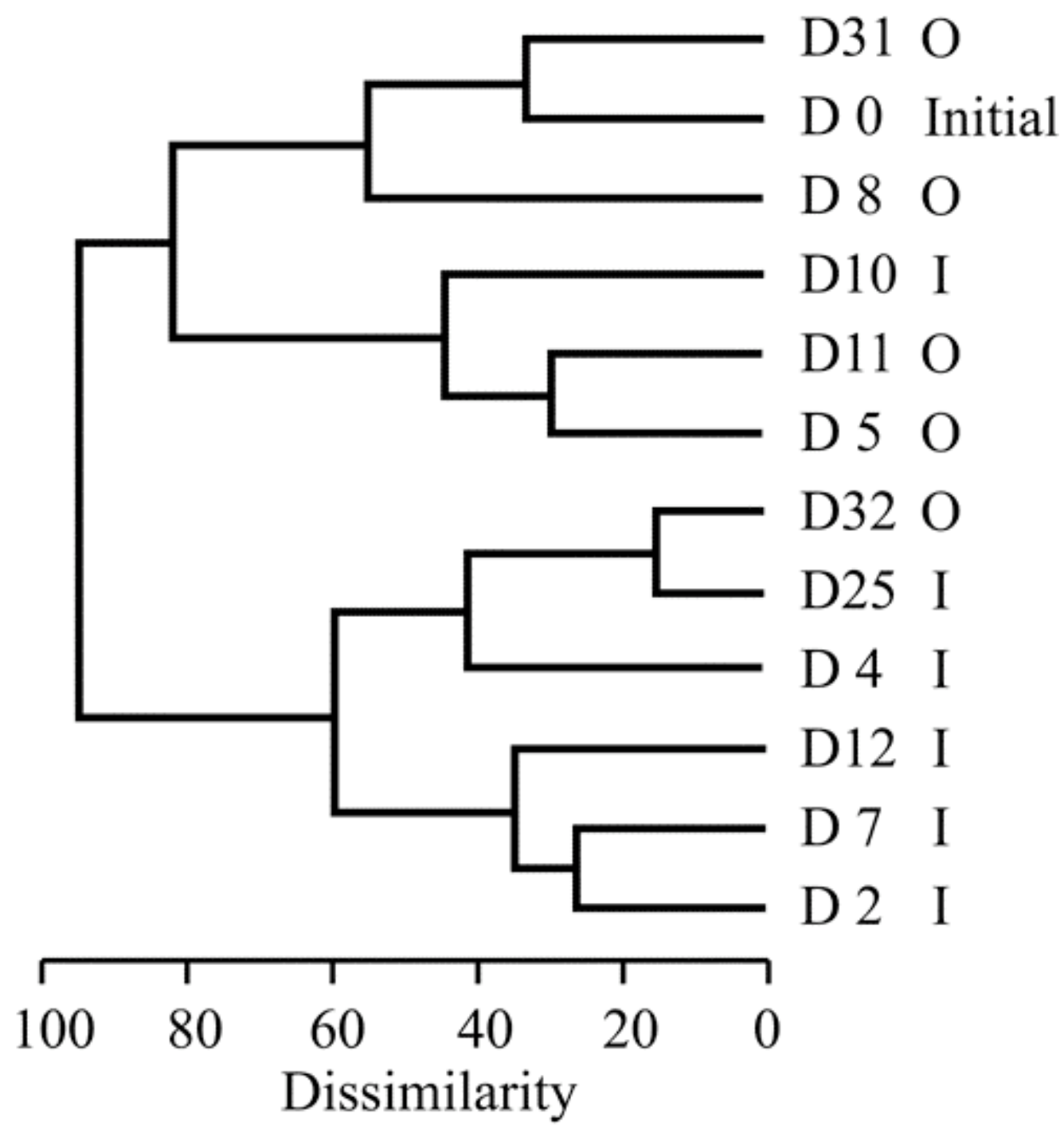

Fig. 3. Cluster analysis of the dissimilarities of denaturing gradient gel electrophoresis (DGGE) profiles shown in Fig. 2. I and O indicate samples from inside and outside the iron-enriched patch, respectively. 


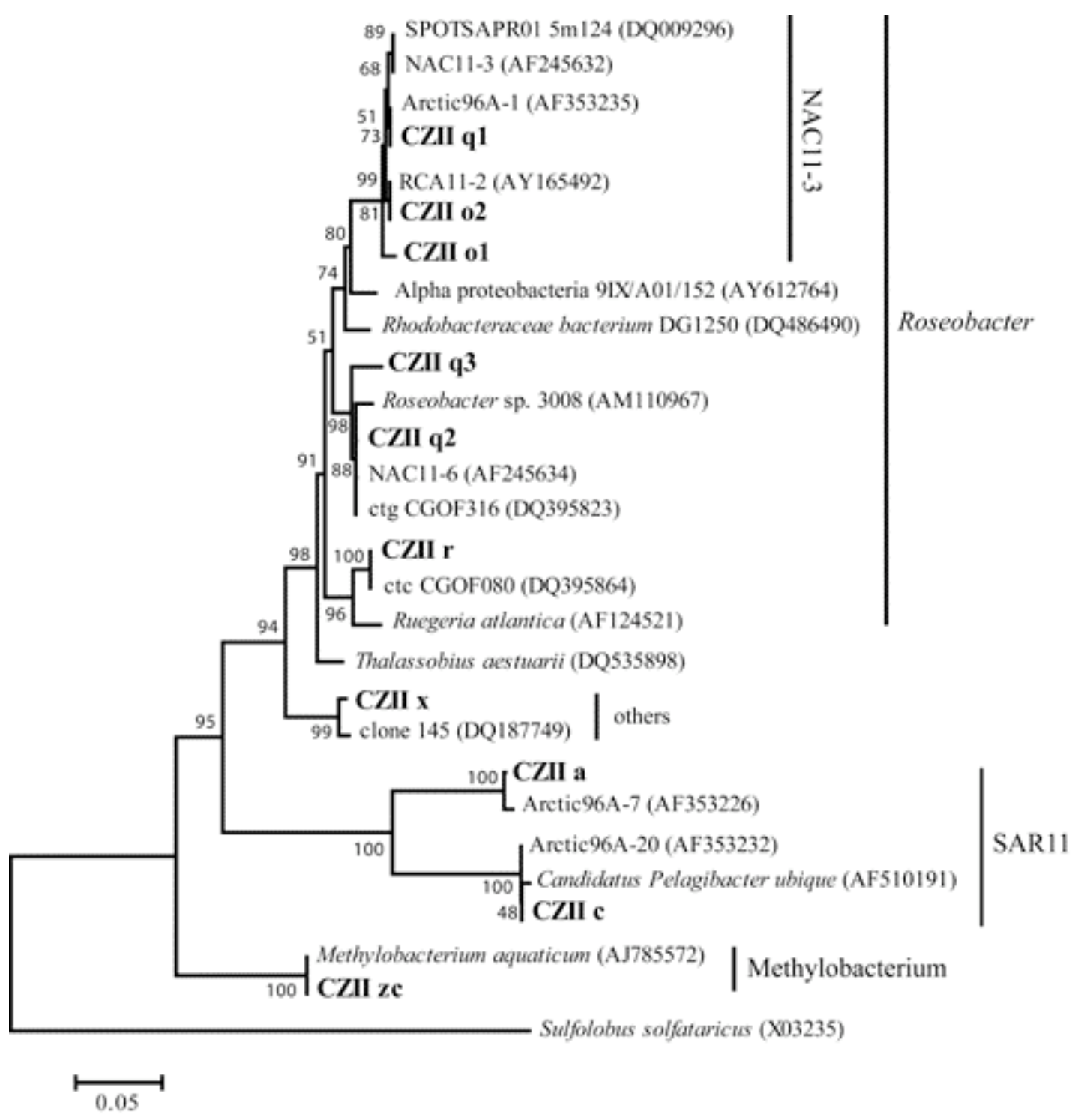

Fig. 4. A neighbor-joining tree of partial 16S rDNA sequences for $\alpha$-proteobacteria obtained from denaturing gradient gel electrophoresis (DGGE) bands (see Fig. 2). The scale bar represents 0.05 substitutions per nucleotide position. 


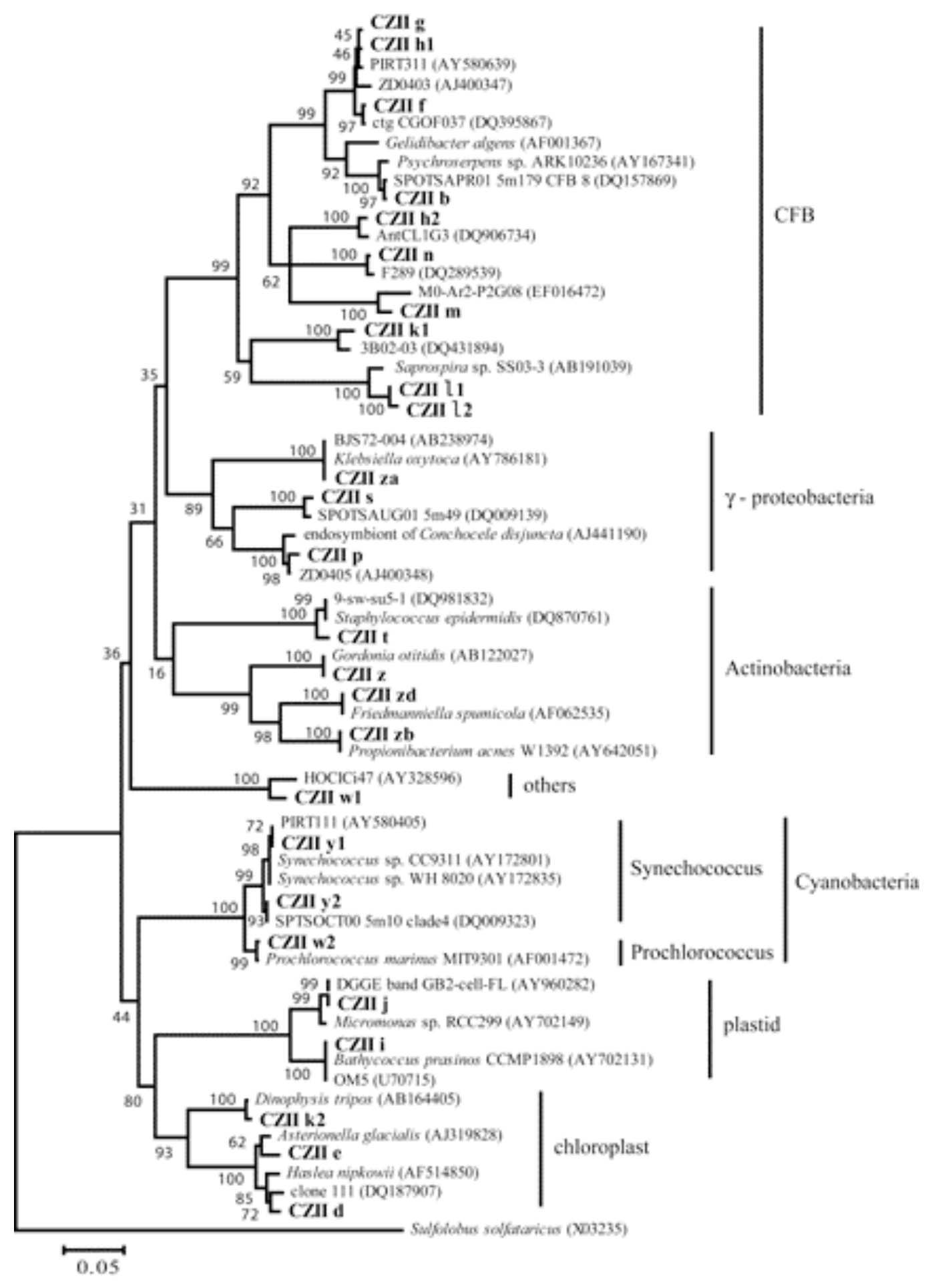

Fig. 5. A neighbor-joining tree of partial 16S rDNA sequences for bacteria other than $\alpha$-proteobacteria. The scale bar represents 0.05 substitutions per nucleotide position. 